\title{
EAl Endorsed Transactions

\section{Feasibility Study Of Rooftop Photovoltaic Power System For A Research Institute Towards Green Building In Vietnam}

\author{
Vu Minh Phap ${ }^{1, *}$, Nguyen Thuy $\mathrm{Nga}^{1}$ \\ ${ }^{1}$ Institute of Energy Science, Vietnam Academy of Science and Technology, Hanoi, Vietnam
}

\begin{abstract}
Use of renewable power technology in urban area can help the buildings to minimize the carbon footprint, meet the electricity needs and achieve the nearly zero-energy building. In this study, the design results of the rooftop grid-tied PV power system with the capacity of $56.7 \mathrm{~kW}$ for a research institute building in Vietnam are analyzed. The study results have calculated the electricity generation, performance of the rooftop grid-tied PV power system as well as reduction potential of the amount of $\mathrm{CO}_{2}$ emitted into the environment. The design results of the rooftop grid-tied PV power system for a research institute building will be compared with the actual power generation results of an installed rooftop grid-tied PV power system at a building of General Directorate of Energy - Vietnam Ministry of Industry and Trade in the same city.
\end{abstract}

Keywords: photovoltaic, inverter, rooftop grid-tied PV power system, loss.

Received on 04 November 2019, accepted on 19 January 2020, published on 30 January 2020

Copyright (C) 2020 Vu Minh Phap et al., licensed to EAI. This is an open access article distributed under the terms of the Creative Commons Attribution licence (http://creativecommons.org/licenses/by/3.0/), which permits unlimited use, distribution and reproduction in any medium so long as the original work is properly cited.

doi: 10.4108/eai.7-1-2020.162825

"Corresponding author. Email: vuminhphap@ies.vast.vn

\section{Introduction}

At the present, building sector achieves a large proportion in power consumption all over the world. Construction of building and other related operations in building sector accounted for $36 \%$ of global final power usage and about $40 \%$ of energy which was related carbon dioxide $\left(\mathrm{CO}_{2}\right)$ emissions [1]. Therefore, governments in the world issued policies towards greener cities and societies by using energy efficiency strategies, renewable energy sources and strategies to fight climate change to decrease the energy consumption of buildings [2-5]. As a kind of sustainable renewable energy source, solar energy can be selected to reduce the pollution and improve energy saving performance of buildings, cities [6-8]. Currently, solar power technology is developing very fast in the world, with a total installed solar power capacity of
509 GW [9]. In 2018, the ground-mounted PV power plant was a major solar market on this type of PV application with the installed capacity of $72.7 \mathrm{GW}$ and it was predicted increasing up to $187.4 \mathrm{GW}$ in 2023 [9]. Besides, the installed capacity of the rooftop PV power stations was $29.7 \mathrm{GW}$ in 2018 and can achieve the target of $76.5 \mathrm{GW}$ in 2023 [9] as illustrated in Figure 1.

Construction of rooftop solar power system in urban area can help the buildings, resident homes in general and the institution buildings in particular to reduce carbon footprint, meet the electricity needs and achieve the nearly zero-energy building (ZEB) characterized by a very highenergy performance during the operation and most of the usage energy is produced from renewable energy sources [typically solar thermal and solar power systems] [10]. However, it is noted that when usage of solar power, a part of $\mathrm{CO}_{2}$ emission also is emitted in the production phase of the photovoltaic modules. 


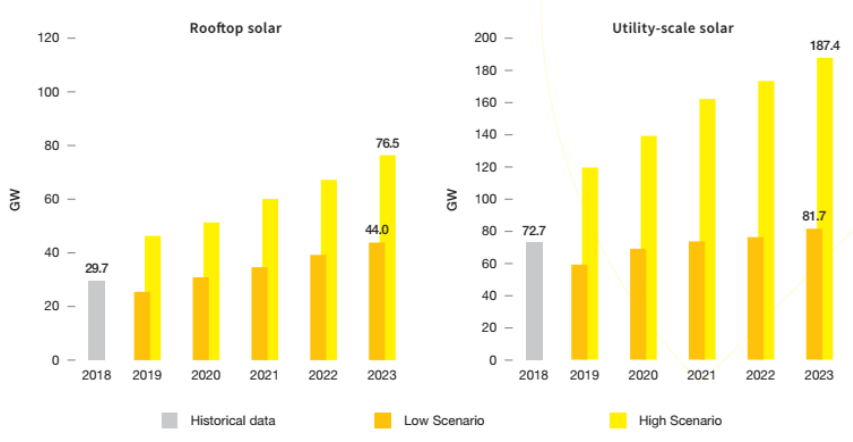

Figure 1. Development of rooftop solar and utility scale solar [1]

Anasuya Gangopadhyay et al [11] studied a $100 \mathrm{~kW}$ grid-tied rooftop solar PV plant which has been operational since October 2014 at National Institute of Advanced Studies, India to evaluate the performance of grid tied rooftop solar plant from generation, economic and maintenance perspective. Daphne Ngar-yin Mah et al [12] reviewed the usage trends of rooftop solar power in urban area and collected data by conducting 57 interviews with potential rooftop solar PV adopters from the residential, institutional, and commercial sectors in Hong Kong to estimate the perceived barriers and effectiveness of possible government policies for solar power. Adel A. Elbaset, M. S. Hassan [13] reseached a new approach for optimum design and implement of rooftop grid connected PV system installation on an institutional building at Minia University, Egypt in order to carry out taking into account PV modules and inverters specifications. Mohammad I et al [14] investigated reduction ways of the electricity demand for Engineering Faculty at Mu'tah University by using the rooftop PV power system with the capacity of $56.7 \mathrm{~kW}$, this plant could generate the electricity of $97.02 \mathrm{MWh}$ per year to the utility grid. Li et al [15] evaluated and compared the techno-economic performance of rooftop grid-connected solar power systems containing 14 families in five climate zones in China. M. MoldovanI, VisaA. Duta [16] presented a nearly zero energy building, solar tracking systems for PV array and solar-thermal convertors, as well as a novel concept for active solar-thermal facades for a sustainable community of the $\mathrm{R} \& \mathrm{D}$ Institute of Transilvania University in Brasov, Romania.

In the case of Vietnam, the electricity demand of administrative and residential buildings increased at an average $9.3 \%$ per annum and achieved an average share of $9.25 \%$ of the whole national power consumption in the period 2010-2016 while energy consumption of commercial buildings have the highest growth rate of about $16.4 \%$ per annum in the same period [17]. Vietnam National Green Growth Strategy [18] was adopted by the government in 2012 with the target for green construction and sustainable urbanization and it was related to the national climate change and economic policy agendas.
Development of green buildings with solar power system is an approach to save energy and plays an important role in cutting greenhouse gas (GHG) emission.

\begin{tabular}{|c|c|c|c|}
\hline NDP pillars & Energy and GHG & $\begin{array}{l}\text { Green production } \\
\text { (industry) }\end{array}$ & Lifestyle \\
\hline $\begin{array}{l}\text { Environmental } \\
\text { conservation }\end{array}$ & $\begin{array}{l}\text { - Target Absolute GHG } \\
\text { decoupling } \\
\text { - Forestry conservation } \\
\text { - Indirect environmental Impact } \\
\text { of new energy sources }\end{array}$ & $\begin{array}{l}\text { - Actual GHG-GDP } \\
\text { decoupling } \\
\text { - Environmental impact } \\
\text { of green industry and } \\
\text { modern agriculture }\end{array}$ & $\begin{array}{l}\text { - Health and security } \\
\text { - Indirect GHG emissions } \\
\text { of new consumption } \\
\text { modes } \\
\text { - Rebound effect }\end{array}$ \\
\hline $\begin{array}{l}\text { Sustainable } \\
\text { and equitable } \\
\text { socio- } \\
\text { economic } \\
\text { development }\end{array}$ & $\begin{array}{l}\text { - Fossil fuels subsidies and } \\
\text { - Climate finance } \\
\text { - Investment cycles and energy } \\
\text { market uncertainty } \\
\text { - Energy dependency (coal) } \\
\text { - Health and security } \\
\text { - Land-use }\end{array}$ & $\begin{array}{l}\text { - Energy pricing } \\
\text { Energy efficiency } \\
\text { potential } \\
\text { - Quality of new green } \\
\text { jobs }\end{array}$ & $\begin{array}{l}\text { - Long-term Energy price } \\
\text { for residential sector and } \\
\text { citizens } \\
\text { - Land-use }\end{array}$ \\
\hline $\begin{array}{l}\text { Preservation } \\
\text { and promotion } \\
\text { of culture }\end{array}$ & $\begin{array}{l}\text { - Population Resettlement } \\
\text { - "Harmony with nature" }\end{array}$ & - Agriculture modes & $\begin{array}{l}\text { - Gap between traditional } \\
\text { Asian culture and new } \\
\text { consumption of emerging } \\
\text { middle-class[AASA 2011] }\end{array}$ \\
\hline $\begin{array}{l}\text { Good } \\
\text { governance }\end{array}$ & $\begin{array}{l}\text { - Decentralization of energy } \\
\text { production sources } \\
\text { - Reliability and efficiency of GG } \\
\text { finance flows }\end{array}$ & $\begin{array}{l}\text { - Industry Accountability } \\
\text { for energy efficiency } \\
\text { - Public-private } \\
\text { partnerships }\end{array}$ & $\begin{array}{l}\text { - Renewable energy } \\
\text { production by residential } \\
\text { sector or communities }\end{array}$ \\
\hline
\end{tabular}

Figure 2. Main specificities of the Vietnam National Green Growth Strategy tasks [18]

Vietnam has good solar energy potential that could be used to successfully develop the solar power sector. Overall solar energy potential in Vietnam is about 4-5 $\mathrm{kWh} / \mathrm{m}^{2}$.day in the Southern area, Central area, and partially even Northern area in Vietnam while the average peak irradiation of up to $5.5 \mathrm{kWh} / \mathrm{m}^{2}$.day in CentralSouthern areas [19]. Solar power has been used in Vietnam since the 1990s but it is mainly used for the remote areas where are far from the national power grid such as mountainous areas, islands, etc.... The small gridtied solar power plants developed from 2010 and installed for the residential applications. The total installed solar power capacity in Vietnam by 2017 is only about 8MW [20], which is very low in comparison with the potential for solar power in Vietnam because there is no policy of the Government to support the development of solar power.

From April in 2017, the Government of Vietnam announced the policy to support the development of solar power in general and the rooftop PV power system in particular. In which, the surplus electricity produced from the rooftop grid-tied PV power station can be sold to the utility grid with the price of 9.35 centUS/kWh [21]. Therefore, investors are interested in constructing the rooftop PV power station in Vietnam.

Since the 2000s, grid-connected PV power systems have been studied for application of building and resident home in Vietnam. Nguyen Xuan Truong et al [22, 23] designed a grid-connected solar power system with the capacity of $15 \mathrm{~kW}$ for a building to achieve nearly zeroenergy building model, the PV arrays were installed in the area of this building to compensate the energy needed and these authors also researched to improve the power production efficiency of the PV system by using the Solar Tracker system. Baulch et al [24] determined the payback period for the rooftop solar power stations in Ho Chi Minh city. General Directorate of Energy (GDE) Vietnamese Ministry of Industry and Trade cooperated 
with Spanish Agency for International Development Cooperation (AECID) [25] to install and test the effectiveness of the grid-tied PV power station in Hanoi city with the capacity of $22 \mathrm{~kW}$ and the off-grid solar power system in Con Dao island with the capacity of $36 \mathrm{~kW}$. German Federal Ministry for Economic Affairs and Energy and GIZ - German Corporation for International Cooperation [26] studied the development potential for solar power rooftop applications in the commercial and industrial sector of Vietnam and to evaluate business opportunities for German solar companies in Vietnam. This report focused on industrial zones and private factories/commercial operations located in Central and Southern Vietnam with the highest solar energy potential.

The rooftop solar power is a new field in the business market in Vietnam. Therefore, this study result will contribute to evaluate the potential of installation of rooftop solar power and reduction of $\mathrm{CO}_{2}$ for buildings in Vietnam. The simulation results of rooftop grid-tied PV power system with the capacity of $56.7 \mathrm{~kW}$ for a research institute building have calculated the solar energy potential in a specialized city, the generation electricity, performance of the rooftop grid-tied PV power system by using PVSYST program as well as reduction amount of $\mathrm{CO}_{2}$ emitted into the environment. The design results of the rooftop grid-tied PV power system for a research institute building will be compared with the actual power generation results of another installed rooftop grid-tied PV power system at the building of General Directorate of Energy - Vietnam Ministry of Industry and Trade in the same city.

\section{Rooftop PV power system}

The main components and working diagram of the typical grid-tied PV power system in Vietnam are presented in Figure 3. In the favorable weather conditions, the PV modules absorb solar energy and generate the power. The $\mathrm{DC} / \mathrm{AC}$ inverter is used to convert the direct current (DC) from the PV module to the alternating current (AC) and transmit it into the utility power grid [27, 28]. At any time of the day, a customer's solar power system may produce more or less electricity than their demand for home or business. When the PV system's power production exceeds the customer's demand, the excess energy generation automatically goes through the electric meter into the utility grid. At other times of the day, when the customer's electric demand may be higher than the electricity production of PV power system, the customer buy the additional power to serve the demand from the utility grid. The connection operation between solar system and the utility grid is instantaneous, so the customers never notice any interruption in the flow of power.

Currently, application of grid-tied PV power technology is increasing fastly in Vietnam. The Bidirectional meter can measure the electricity in two directions and it measures how much energy comes from the power company versus the electricity production from the PV power systems. If more electric energy is produced from the PV system than the customer's demands, the surplus electricity is supplied into the utility's electric system. By which, the surplus electricity produced from grid-tied PV power station can be sold to the utility grid with the price of 9.35 centUS/kWh [21].
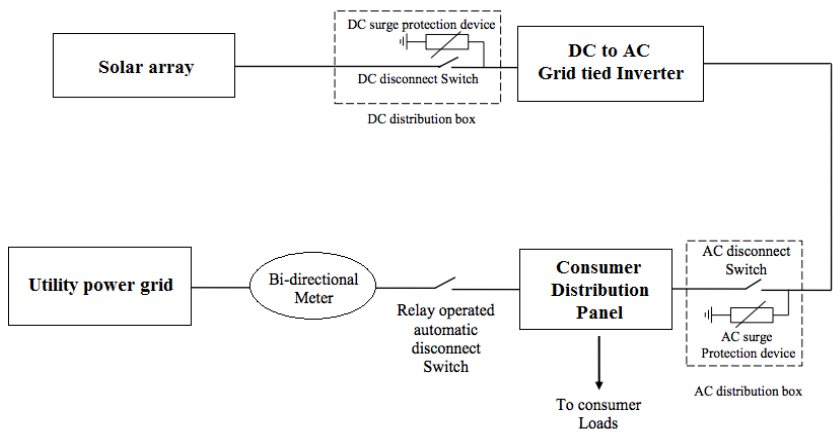

Figure 3. Working diagram of the typical grid-tied PV power system in Vietnam

\section{Design of PV system at Institute of Geological Science}

\subsection{Site description}

The Institute of Geological Science (IGS) under Vietnam Academy of Science and Technology is responsible for scientific research and training on geological and climate change issues. The electricity from grid-tied PV power system will be supplied for buildings, research work and teaching rooms. After the PV power system is completed, IGS will cooperate with other universities and institutions to train environmental geology, geotechnics, energy, environment classes.

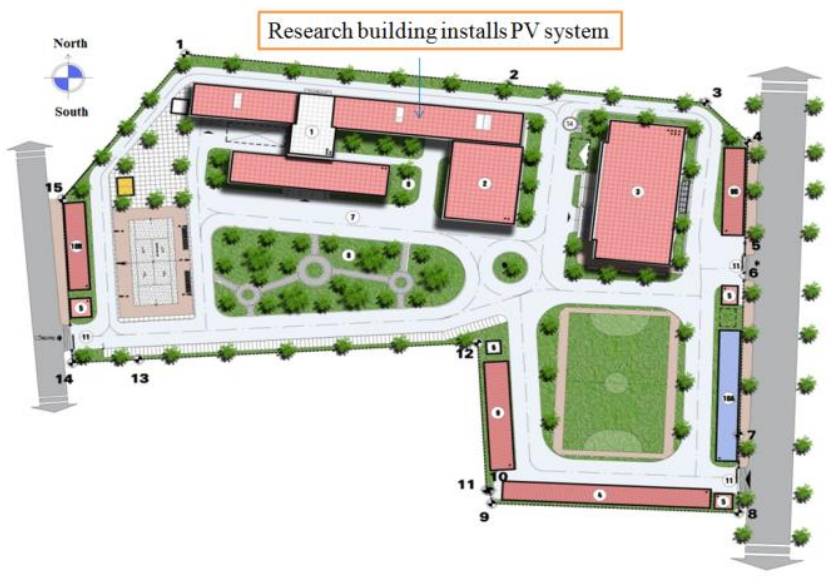

Figure 4. Plan of IGS 
The research building in IGS is located at latitude of $21^{\circ} 01^{\prime} 29^{\prime \prime} \mathrm{N}$ and longitude of $105^{\circ} 48^{\prime} 18^{\prime \prime} \mathrm{E}$. The roof of the research building is a concrete roof system and the area of the roof is suitable for constructing the PV power system as shown in Figure 5.

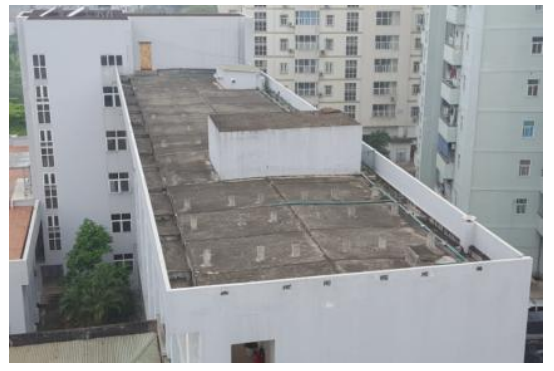

Figure 5. Plan of roof on research building at IGS

\subsection{Performance calculation parameters}

In this study, the design of the rooftop grid-tied PV power system with the capacity of $56.7 \mathrm{~kW}$ for a research building in IGS was implemented by using specialized software PVSYST [29-34].

In PVSYST program [31, 35-38], the losses, yield factor, performance ratio are determined as below:

Array Yield $\left(Y_{a}\right)$ :

$$
Y_{a}=\frac{E_{a}}{P_{0}}
$$

where, $\mathrm{P}_{0}$ is power of solar array $[\mathrm{kWp}] ; \mathrm{E}_{\mathrm{a}}$ is output array yield [kWh]; $\mathrm{Y}_{\mathrm{a}}$ (Array Yield) is the array daily output energy, referred to the nominal power $[\mathrm{kWh} / \mathrm{kWp} /$ day].

Reference system Yield $\left(Y_{r}\right)$ :

$$
Y_{r}=\frac{H_{t}}{G_{0}}
$$

where, $\mathrm{Y}_{\mathrm{r}}$ (Reference system Yield) is numerically equal to the incident energy in the array plane $\left[\mathrm{kWh} / \mathrm{m}^{2} /\right.$ day $] . \mathrm{H}_{\mathrm{t}}$ is the total horizontal irradiance on array $\left[\mathrm{kWh} / \mathrm{m}^{2}\right]$ and $\mathrm{G}_{\mathrm{o}}$ is the global irradiance at standard condition (STC) $\left(\mathrm{W} / \mathrm{m}^{2}\right)$.

System Yield $\left(Y_{f}\right)$.

$$
Y_{f}=\frac{E_{\text {ACout }}}{P_{\max }, S T C}
$$

where, $\mathrm{Y}_{\mathrm{f}}$ (System Yield) is the system daily useful energy, referred to the nominal power $[\mathrm{kWh} / \mathrm{kWp} / \mathrm{day}]$; EACout is the amount of electrical energy generated by the solar power plant; Pmax, STC is the total installed power of solar arrays at standard test condition (STC).

Performance Ratio (PR):

$$
P R=\frac{Y_{f}}{Y_{r}}
$$

where, PR (Performance Ratio) is the global system efficiency with respect to the nominal installed power and the incident energy; $\mathrm{Y}_{\mathrm{f}}$ is System Yield; $\mathrm{Y}_{\mathrm{r}}$ is Reference system Yield.

Collection Loss $\left(L_{c}\right)$ :

$$
\mathrm{L}_{\mathrm{c}}=\mathrm{Y}_{\mathrm{r}}-\mathrm{Y}_{\mathrm{a}}
$$

where, $\mathrm{L}_{\mathrm{c}}$ (Collection Loss) is the array losses, including thermal, wiring, module quality, mismatch and IAM losses, shading, dirt, MPP, regulation losses, as well as all other inefficiencies; $\mathrm{Y}_{\mathrm{r}}$ is Reference system Yield; $\mathrm{Ya}$ is Array Yield.

System Loss (Ls):

$$
\mathrm{L}_{\mathrm{s}}=\mathrm{Y}_{\mathrm{a}}-\mathrm{Y}_{\mathrm{f}}
$$

where, $\mathrm{L}_{\mathrm{s}}$ (System Loss) is inverter loss in grid-tied solar power system; $\mathrm{Y}_{\mathrm{a}}$ is Array $\mathrm{Yield}$; $\mathrm{Y}_{\mathrm{f}}$ is System Yield.

\subsection{Design of solar power system}

In Vietnam, Hanoi city has the fairly solar energy potential with an average annual solar radiation of $3.85 \mathrm{kWh} / \mathrm{m}^{2}$.day [39]. The period from January to March and from October to December has the lowest daily average solar radiation value from $2.49 \mathrm{kWh} / \mathrm{m}^{2}$.day to $3.66 \mathrm{kWh} / \mathrm{m}^{2}$.day while the daily average solar radiation in the period from April to October has a good value from $3.79 \mathrm{kWh} / \mathrm{m}^{2}$.day to $4.67 \mathrm{kWh} / \mathrm{m}^{2}$.day.

Table 1. Daily solar radiation value in Hanoi city

\begin{tabular}{cc}
\hline Month & $\begin{array}{c}\text { Solar radiation } \\
\left(\mathrm{kWh} / \mathrm{m}^{2} . \text { day }\right)\end{array}$ \\
\hline 1 & 2.49 \\
2 & 2.86 \\
3 & 3.66 \\
4 & 4.07 \\
5 & 4.59 \\
6 & 4.67 \\
7 & 4.60 \\
8 & 4.56 \\
9 & 4.39 \\
10 & 3.79 \\
11 & 3.39 \\
12 & 3.02 \\
Average year & 3.85 \\
\hline
\end{tabular}

Solar panels are installed on the roof system of the research building in IGS with the slope angle of $18^{\circ}$ and the azimuth angle of $0^{0}$ in order to achieve the best energy conversion efficiency.

Figure 7 presents the diagram of PV system connection at the research building with the connection structure as below:

The $1^{\text {st }}$ inverter of $25 \mathrm{~kW}$ consists of 4 solar panel strings. Each string consists of 13 mono-crystalline silicon solar panels of $350 \mathrm{~W}$ that are connected in series. Two 
strings are connected to input of a Maximum power point tracking (MPPT) tracker of the grid-tied inverter.

The $2^{\text {nd }}$ inverter of $25 \mathrm{~kW}$ consists of 4 solar panel strings. Each string consists of 14 mono-crystalline silicon solar panels of $350 \mathrm{~W}$ that are connected in series. Two strings are connected to input of a Maximum power point tracking (MPPT) tracker of the grid-tied inverter.

The $3^{\text {rd }}$ inverter of $25 \mathrm{~kW}$ have 4 solar panel strings. In which, 2 strings consist of 13 mono-crystalline silicon solar panels of $350 \mathrm{~W}$ in series connection and they are connected to inputs of the first MPPT tracker of the gridtied inverter. 2 strings include 14 mono-crystalline silicon solar panels of $350 \mathrm{~W}$ in series connection and this string is connected to the input of the second MPPT tracker of the grid-tied inverter.

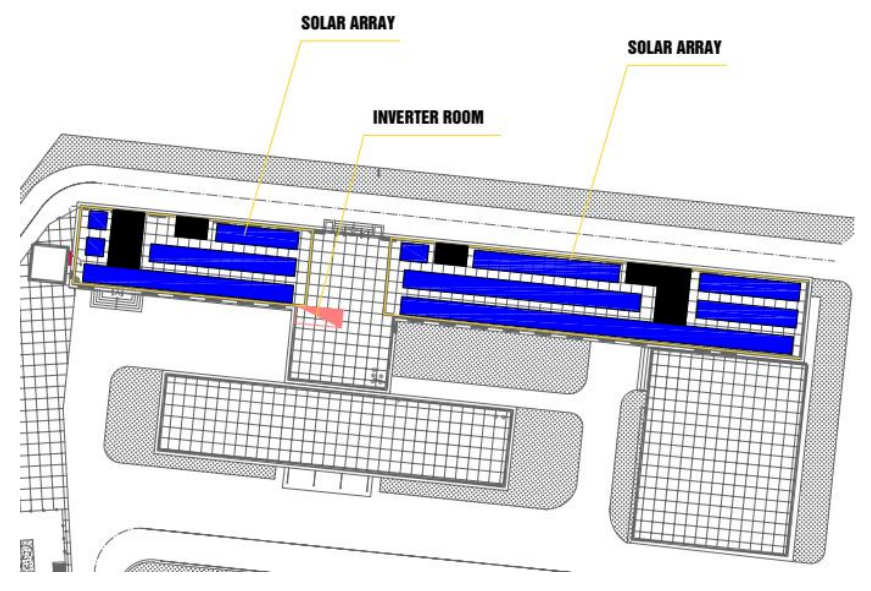

Figure 6. Arrangement of solar panel on the roof of the research building

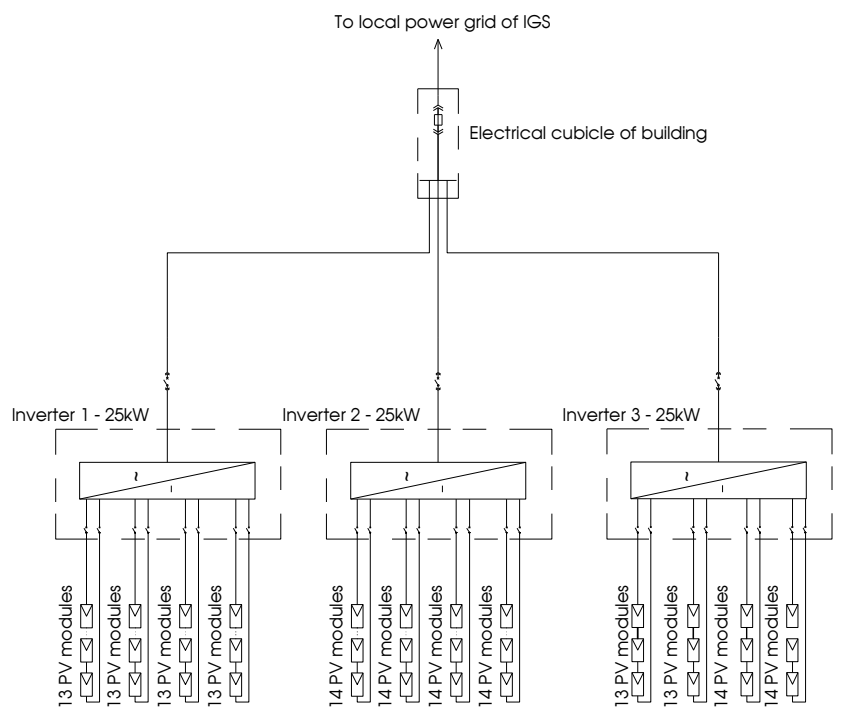

Figure 7. Diagram of PV system connection at the research building
Table 2 shows the main equipments of the the grid-tied $\mathrm{PV}$ power station in IGS. Table 2. Main equipments of the the grid-tied PV
power station

\begin{tabular}{|c|c|c|c|}
\hline No & Equipments & Quantity & Unit \\
\hline 1 & $\begin{array}{l}\text { Solar panel - SolarWorld } 350 \mathrm{~W} \\
\text { - Maximum power: } 350 \mathrm{~W} \\
\text { - Open circuit voltage: } 47.3 \mathrm{~V} \\
\text { - MPP voltage: } 37.8 \mathrm{~V} \\
\text { - Short circuit current: } 9.82 \mathrm{~A} \\
\text { - MPP current: } 9.29 \mathrm{~A} \\
\text { - Module efficiency: } 17.54 \%\end{array}$ & 162 & module \\
\hline 2 & $\begin{array}{l}\text { Grid-tied Inverter - SMA } 25 \mathrm{~kW} \\
\text { - Max input voltage: } 1000 \mathrm{~V} \\
\text { - MPPT voltage range: } 390 \mathrm{~V} \text { - } \\
800 \mathrm{~V} \\
\text { - Min input voltage: } 150 \mathrm{~V} \\
-\quad \text { Max input current input } \\
\text { A/inputB: } 33 \mathrm{~A} / 33 \mathrm{~A} \\
\text { - Rated power (at } 230 \mathrm{~V}, 50 \mathrm{~Hz} \text { ): } \\
25 \mathrm{~kW} \\
-\quad \mathrm{AC} \text { voltage range: } 180 \mathrm{~V}- \\
280 \mathrm{~V} \\
-3 \text { phases }\end{array}$ & 3 & unit \\
\hline
\end{tabular}

\subsection{Study result}

PVSYST software is used to calculate the power output, performance as well as the losses of the grid connected PV power station. The types of losses include the Collection loss and the System loss.

Figure 8 presents the loss diagram of the PV power station, it is can be seen that the PV loss due to temperature is the highest value of about $4.8 \%$ because Hanoi is in the Northern area of Vietnam. Thus, the temperature difference between four seasons is quite high and not close to the standard working temperature of solar panels of $25^{\circ} \mathrm{C}$, the temperature in summer can reach $45^{\circ} \mathrm{C}$ while the temperature in winter can be reduced to $8^{\circ} \mathrm{C}$. On the other hand, the loss of $\mathrm{AC}$ wire connecting to the grid power point is the lowest value of $0.3 \%$ because the connection distance is only about $22 \mathrm{~m}$. The types of losses will affect the output electricity per $\mathrm{kW}$ generated to the power grid and the efficiency of grid connected solar power stations as shown in Figure 10, the generated power by the loss of $13.2 \%$ caused by solar arrays is about $0.53 \mathrm{kWh} / \mathrm{kWp} /$ day while the generated power affected by the system loss of $4.4 \%$ is about $0.18 \mathrm{kWh} / \mathrm{kWp} /$ day, the amount of produced useful electricity at inverter output is only about $3.32 \mathrm{kWh} / \mathrm{kWp} /$ day. Hence, the solar power station performance shown in Figure 9 will only reach about $82.4 \%$ 


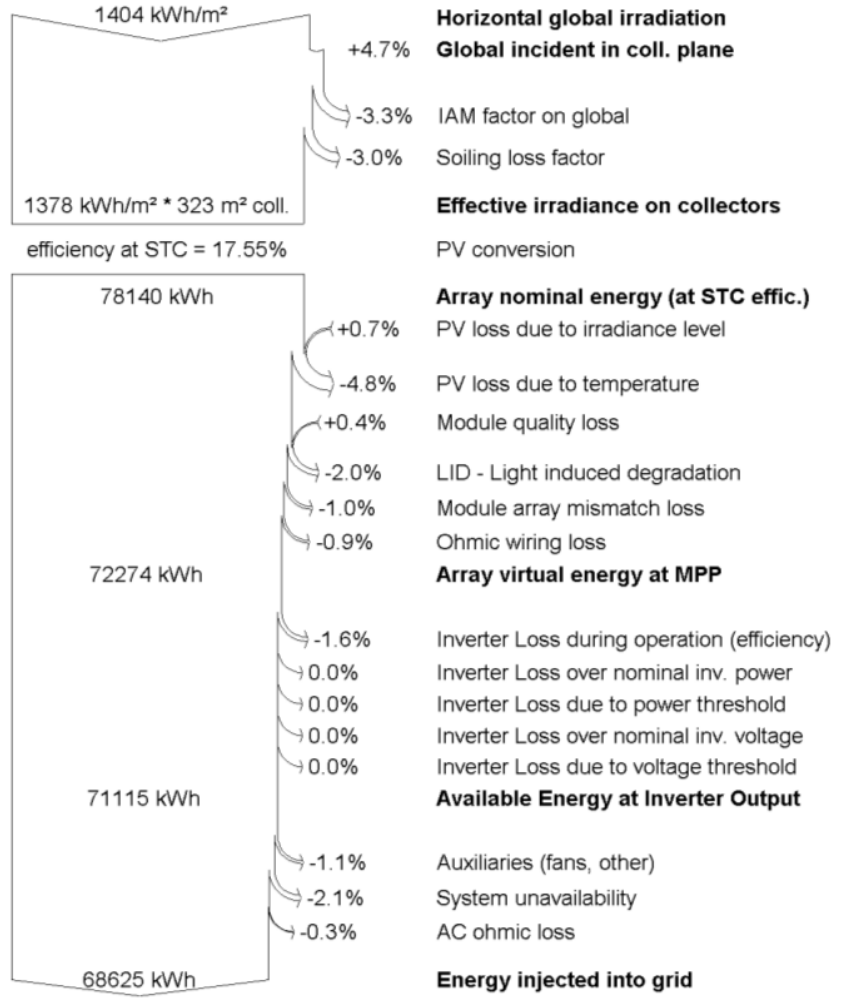

Figure 8. Loss diagram of PV power station

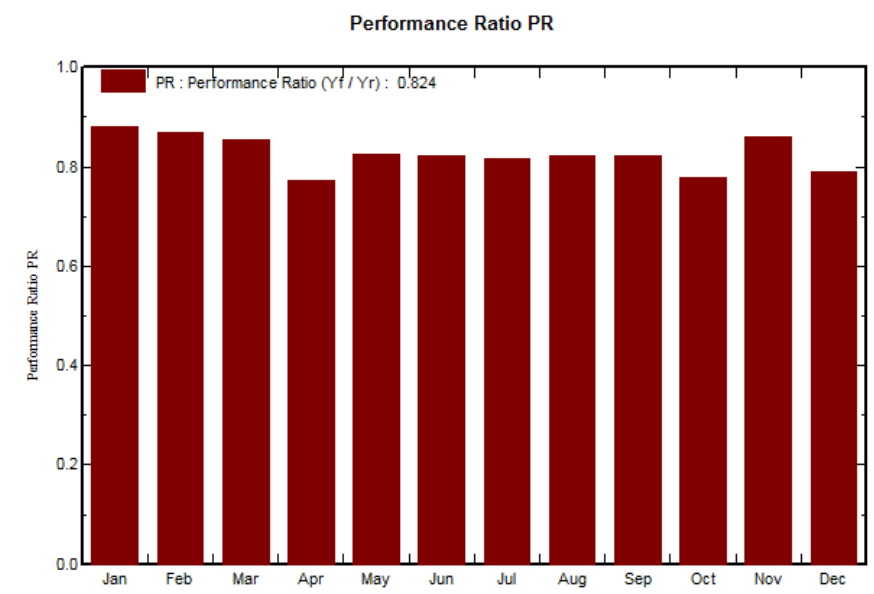

Figure 9. Performance ratio

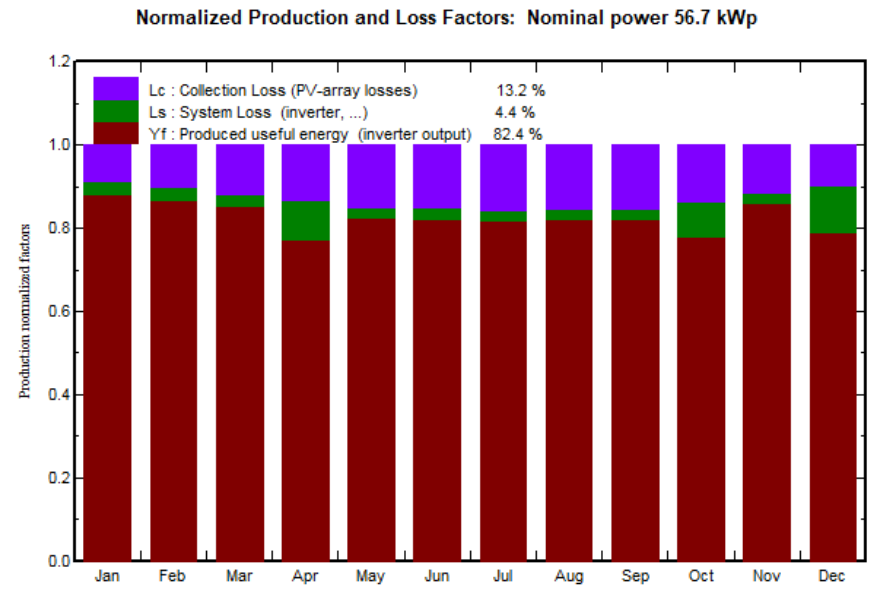

Normalized productions (per installed kWp): Nominal power 56.7 kWp

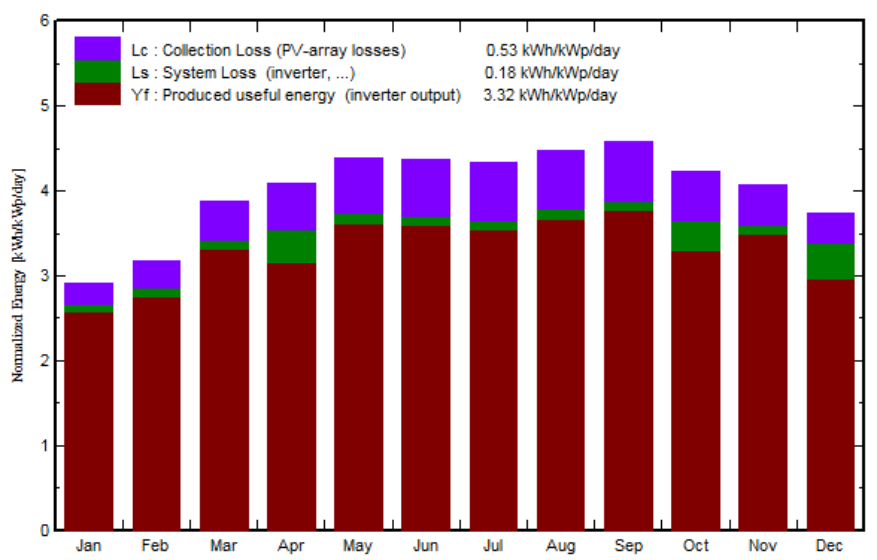

Figure 10. Types of losses versus output power

It is can be seen that the generated power from the PV power system in Figure 11 corresponding to the solar radiation value. The time period from May to September has the highest power generation while January and February in the remaining months of the year have the lowest power output. On the other hand, the Global on tilted plane with the solar array slope angle of $18^{0}$ is about $0.2 \mathrm{kWh} / \mathrm{kWp} / \mathrm{day}$ higher than the case of GlobHor horizontal as shown in Figure 12. Total annual average electricity from the solar power station transmitting to the utility grid is $68625 \mathrm{kWh}$ per year. 


\begin{tabular}{|l|c|c|c|c|c|c|c|c|}
\hline & $\begin{array}{c}\text { GlobHor } \\
\mathrm{kWh} / \mathrm{m}^{2}\end{array}$ & $\begin{array}{c}\mathbf{T} \text { Amb } \\
{ }^{\circ} \mathrm{C}\end{array}$ & $\begin{array}{c}\text { Globlnc } \\
\mathrm{kWh} / \mathrm{m}^{2}\end{array}$ & $\begin{array}{c}\text { GlobEff } \\
\mathrm{kWh} / \mathrm{m}^{2}\end{array}$ & $\begin{array}{c}\text { EArray } \\
\mathrm{kWh}\end{array}$ & $\begin{array}{c}\text { E_Grid } \\
\mathrm{kWh}\end{array}$ & $\begin{array}{c}\text { EffArrR } \\
\%\end{array}$ & $\begin{array}{c}\text { EffSysR } \\
\%\end{array}$ \\
\hline January & 77.2 & 11.70 & 90.3 & 84.6 & 4672 & 4517 & 16.01 & 15.48 \\
February & 80.1 & 13.50 & 88.9 & 83.5 & 4528 & 4379 & 15.75 & 15.23 \\
March & 113.5 & 17.20 & 120.5 & 113.1 & 6020 & 5832 & 15.46 & 14.98 \\
April & 122.1 & 21.50 & 122.5 & 114.7 & 6021 & 5375 & 15.21 & 13.58 \\
May & 142.3 & 24.20 & 136.2 & 127.5 & 6563 & 6368 & 14.91 & 14.47 \\
June & 140.1 & 26.10 & 131.2 & 122.6 & 6307 & 6121 & 14.88 & 14.44 \\
July & 142.6 & 26.30 & 134.4 & 125.7 & 6424 & 6230 & 14.79 & 14.34 \\
August & 141.4 & 26.00 & 138.6 & 129.8 & 6654 & 6460 & 14.85 & 14.42 \\
September & 131.7 & 24.30 & 137.4 & 129.2 & 6602 & 6408 & 14.87 & 14.43 \\
October & 117.5 & 21.10 & 131.0 & 123.3 & 6408 & 5783 & 15.13 & 13.66 \\
November & 101.7 & 17.30 & 122.0 & 114.8 & 6129 & 5951 & 15.54 & 15.09 \\
December & 93.6 & 13.29 & 116.1 & 109.0 & 5946 & 5199 & 15.84 & 13.86 \\
\hline Year & 1403.8 & 20.24 & 1469.2 & 1377.9 & 72274 & 68625 & 15.22 & 14.45 \\
\hline
\end{tabular}

Figure 11. Total annual average electricity from the solar power station

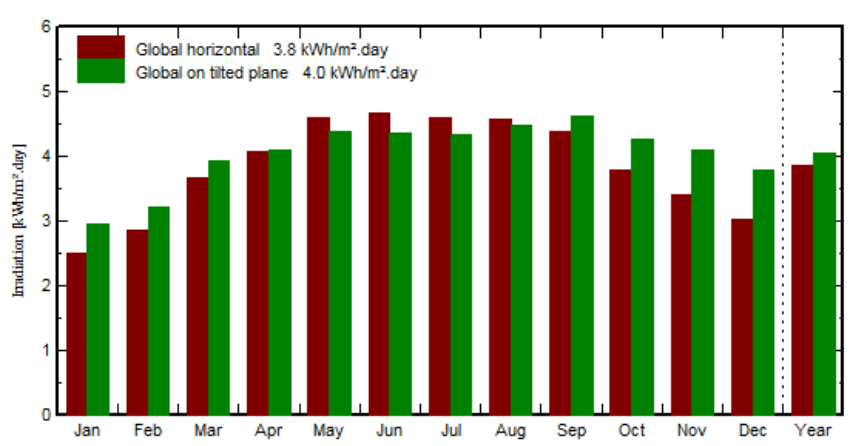

Figure 12. Global on tilted plane versus Global horizontal

\subsection{Environmental impact}

At the present, the investment in construction of gridconnected solar power stations can obtain the economic profit and contribute to environmental protection, combat the phenomenon of climate change by reducing the amount of $\mathrm{CO}_{2}$ emitted into the environment [40]. The annual average reduction of $\mathrm{CO}_{2}$ in IGS building is 59.3 ton per year by using the following formula [41]:

where:

$$
\mathrm{t}_{\mathrm{CO} 2 \mathrm{e}}=\mathrm{E} \_ \text {Grid } x \mathrm{EF}_{\text {grid }}
$$

E_Grid - the average annual generation electricity from the solar power station (MWh)

$\mathrm{EF}_{\text {grid }}\left(\mathrm{CO}_{2}\right.$ emission factor of Vietnamese power grid $)=$ $0.8649 \mathrm{tCO}_{2} / \mathrm{MWh}[41]$

\section{Comparison of design result with another real work}

The results of the design of the grid connected solar power station at the IGS is compared with the actual power generation results of a grid connected solar power station at the General Directorate of Energy building (GDE) [25] as can be seen in table 3 because these projects has the same city location in Vietnam.

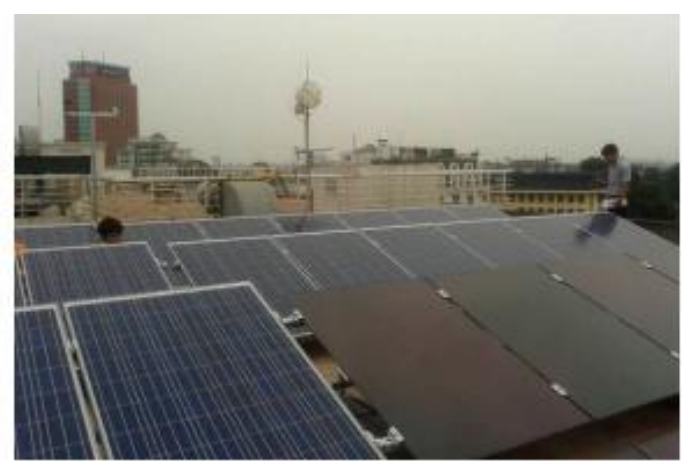

Figure 13. GDE building solar PV system [25]

The solar power station using poly-crystalline silicon solar panels and thin film was installed on the roof of the GDE's building, 23 Ngo Quyen street, Hanoi city at a latitude of $21^{\circ} 01^{\prime} 27^{\prime \prime} \mathrm{N}$ and longitude of $105^{\circ} 51^{\prime} 18^{\prime \prime} \mathrm{E}$. The total capacity of poly-crystalline silicon solar panels in this project was $11 \mathrm{~kW}$ including 48 modules of $240 \mathrm{~W}$ of Atersa manufacturer, 01 inverters of $11 \mathrm{~kW}$ of Ingeteam manufacturer while the total capacity of thin film solar panels was $11 \mathrm{~kW}$ including 91 modules of $120 \mathrm{~W}$ of Sharp manufacturer, 01 inverters of $11 \mathrm{~kW}$ of Ingeteam manufacturer. 
Table 3. Comparative parameters of solar power station

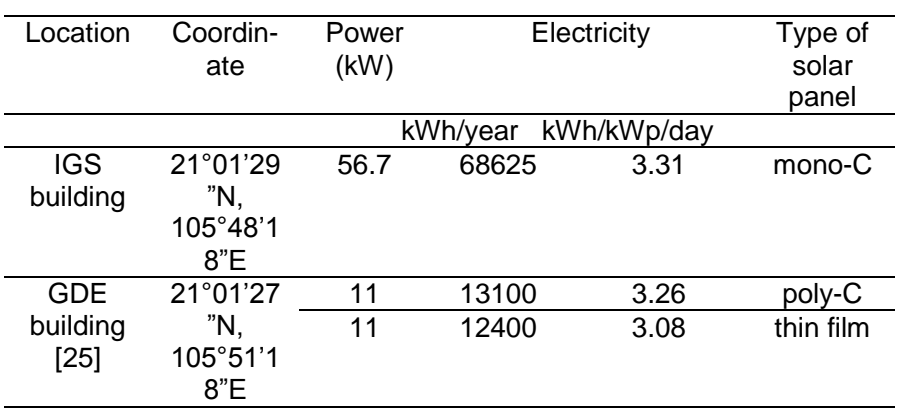

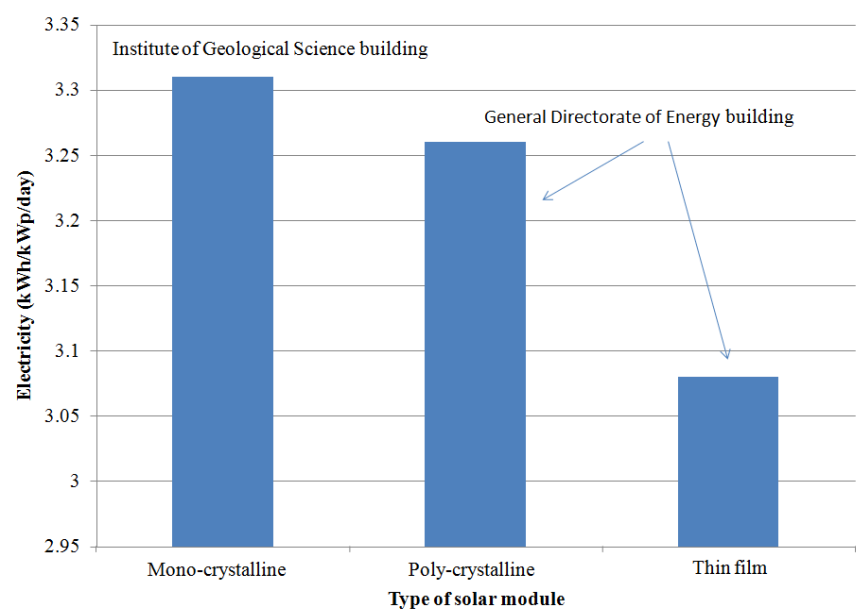

Figure 14. Comparative parameters of solar power stations in Hanoi city

The results of comparing electricity from two solar power stations with the same coordinates in Hanoi and similar solar radiation conditions showed that the electricity of the design results of the solar power station of the IGS building are $0.05 \mathrm{kWh} / \mathrm{kWp} /$ day and $0.23 \mathrm{kWh} / \mathrm{kWp} /$ day higher than the electricity from the PV power system of GDE building using polycrystalline solar panels and thin film solar panels, respectively, because monocrystalline solar cell performance is higher than performance of polycrystalline solar cell and thinfilm solar cell. On the other hand, solar power stations can be more affected by dust losses, climatic conditions in real operation conditions in comparion with the calculations in design stage.

\section{Conclusion}

The power output generated to the utility grid and the performance of grid-connected solar power stations are affected by different types of losses. In which, the loss of solar panels due to temperature has the highest value of about $4.8 \%$ because Hanoi city in the Northern region has a high temperature difference between seasons. So the performance of solar power station at the IGS building is about $82.4 \%$.

The results of comparing electricity from two solar power stations with the same coordinates in Hanoi city and similar solar radiation conditions showed that the electricity of the design results of the solar power station of the IGS building are $0.05 \mathrm{kWh} / \mathrm{kWp} /$ day and $0.23 \mathrm{kWh} / \mathrm{kWp} /$ day higher than the electricity from $\mathrm{PV}$ system of GDE building using polycrystalline solar panels and thin film solar panels, respectively.

Moreover, construction of rooftop grid-tied solar power station at IGS building can help reduce the amount of $\mathrm{CO}_{2}$ of 59.3 tons per year emitted into the environment, so it will contribute to environmental protection and combat the phenomenon of climate change in the city.

Finally, installation of rooftop PV system in Vietnam can help to save energy for the buildings, reduce greenhouse gas emission in the environment, and contribute to achieve targets of the Vietnam National Green Growth Strategy for green construction and sustainable urbanization.

\section{References}

[1] International Energy Agency (IEA) and the United Nations Environment Programme. (2018) 2018 Global Status Report Towards a zero emission, efficient and resilient buildings and construction sector.

[2] Jia-Jun Ma, Gang Du , Bai-Chen Xie, Zhen-Yu She, Wei Jiao. (2015) Energy Consumption Analysis on a Typical Office Building: Case study of the Tiejian Tower, Tianjin. Energy Procedia, 75, 2745 - 2750.

[3] Carmen de la Cruz-Lovera et al. (2017) Worldwide Research on Energy Efficiency and Sustainability in Public Buildings. Sustainability, 9, 1294.

[4] Khaled Bataineh and Ayham Alrabee. (2018) Improving the Energy Efficiency of the Residential Buildings in Jordan. Buildings, 8, 85.

[5] Isidoros Ziogou, Apostolos Michopoulos, Vasiliki Voulgari, Theodoros Zachariadis. (2018) Implementation of green roof technology in residential buildings and neighborhoods of Cyprus. Sustainable Cities and Society, 40, 233-243.

[6] Kirk Dimond, Amy Webb. (2017) Sustainable roof selection: Environmental and contextual factors to be considered in choosing a vegetated roof or rooftop solar photovoltaic system. Sustainable Cities and Society, 35, 241-249.

[7] David Parra, Gavin S Walker, Mark Gillott. (2014) Modeling of PV generation, battery and hydrogen storage to investigate the benefits of energy storage for single dwelling. Sustainable Cities and Society, 10, 110.

[8] Jouri Kanters \& Maria Wall. (2018) Experiences from the urban planning process of a solar neighbourhood in Malmö, Sweden. Urban, Planning and Transport Research, 6(1), 54-80.

[9] SolarPower Europe. (2019) Global Market Outlook For Solar Power/2019 - 2023.

[10] Patxi Hernandez, Xabat Oregi, Sonia Longo, Maurizio Cellura. (2019) Handbook of Energy Efficiency in 
Buildings: A Life Cycle Approach. ButterworthHeinemann, 207-261.

[11] Anasuya Gangopadhyay, Hippu Salk Kristle Natha. (2017) Institutional rooftop solar: NIAS experience with a $100 \mathrm{kwp}$ solar system, National Institute of Advanced Studies.

[12] Daphne Ngar-yin Mah et al. (2018) Barriers and policy enablers for solar photovoltaics (PV) in cities: Perspectives of potential adopters in Hong Kong. Renewable and Sustainable Energy Reviews, 92, 921936.

[13] Adel A. Elbaset, M. S. Hassan. (2015) Design and implement of $100 \mathrm{~kW}$ rooftop grid connected PV system: Faculty of engineering as a case study. Proceeding of $3^{\text {rd }}$ International Conference on Energy Systems and Technologies, Cairo, Egypt.

[14] Mohammad I, Al-Najideen Saad, S. Alrwashdeh. (2017) Design of a solar photovoltaic system to cover the electricity demand for the faculty of Engineering Mu'tah University in Jordan. Resource Efficient Technologies, 3(4), 440-445.

[15] Li, Chong \& Zhou, Dequn \& Zheng, Yuan. (2018) Techno-economic comparative study of gridconnected PV power systems in five climate zones, China. Energy, 165, 1352-1369.

[16] M. MoldovanI, VisaA. Duta. (2016) Future trends for solar energy use in nearly zero energy buildings. Advances in Solar Heating and Cooling, 547-569.

[17] Programme for Energy Efficiency in Buildings. (2019) Building Sector Brief: Vietnam.

[18] Jerome Meessen, Claude Croizer, Paul Verle. (2015) The Viet Nam Green Growth Strategy: A review of specificities, indicators and research perspectives. Proceeding of Conference: 2ieme Congrès Interdisciplinaire Du Développement Durable, 1-13.

[19] Van Vang Le, Danh Chan Nguyen, Van Huong Dong. (2017) The Renewable Energy In Vietnam: Potential, Development Orientation. International Journal Of Scientific \& Technology Research, 6, 8 .

[20] International Renewable Energy Agency. (2018) Renewable capacity statistics 2018.

[21] Prime Minister of Vietnam. (2017) Decision No: 11 /2017/QD-TTg On the Support mechanisms for the Development of Solar Power Projects in Vietnam.

[22] N. X. Truong, N. L. Tung, N. Q. Hung and B. Delinchant. (2016) Grid-connected PV system design option for nearly zero energy building in reference building in Hanoi. Proceeding of 2016 IEEE International Conference on Sustainable Energy Technologies (ICSET), Hanoi, 326-331.

[23] Xuan Truong Nguyen, Viet Dung Nguyen, Dinh Quang Nguyen, Lang Tung Nguyen, Duc Quang Nguyen. (2017) Performance comparison between tracking and fixed photovoltaic system: A case study of Hoa Lac Hi-tech Park, Hanoi. Proceeding of 2017 International Seminar on Intelligent Technology and Its Applications (ISITIA), Surabaya, 128-133.

[24] Baulch, Bob and Do, Thuy Duong and Le, Thai-Ha. (2015) Solar Home Systems in Ho Chi Minh City: A promising technology whose time has not yet come.

[25] General Directorate of Energy - Vietnam Ministry of Industry and Trade. (2015) Final report: Final external evaluation and lessons learnt from the "Impulse to the Development of the Renewable Energies Industrial Sector, in particular Solar Energy, based on the Spanish experience Project.
[26] German Federal Ministry for Economic Affairs and Energy and GIZ - German Corporation for International Cooperation. (2016) Subsector Analysis: Vietnam Solar PV Rooftop Investment Opportunities in Vietnam. Publisher of Federal Ministry for Economic Affairs and Energy (BMWi), Berlin.

[27] Michael Boxwell. (2019) Solar Electricity Handbook - 2019 Edition: A simple, practical guide to solar energy - designing and installing solar photovoltaic systems. Greenstream Publishing.

[28] Vu Minh Phap, Yamamura, N., Ishida, M. et al. (2019) Study on Novel Topology of Solar-Wind Hybrid Power Plant Using Photovoltaic Cell Emulating System. Journal of Electrical Engineering \& Technology, 14, 627-634.

[29] A. Soualmia and R. Chenni. (2016) Modeling and simulation of $15 \mathrm{MW}$ grid-connected photovoltaic system using PVsyst software. Proceeding of IEEE International Renewable and Sustainable Energy Conference (IRSEC), Marrakech, 702-705.

[30] B.Shiva Kumar, K.Sudhakar. (2015) Performance evaluation of 10 MW grid connected solar photovoltaic power plant in India. Energy Reports, 1, 184-192.

[31] PVsyst, "PVsyst Photovoltaic Software." [Online]. Available: http://www.pvsyst.com/en/.

[32] N.M. Kumar, M.R. Kumar, P.R. Rejoice, M. Mathew. (2017) Performance analysis of $100 \mathrm{kWp}$ grid connected Si-poly PV system using PVsyst simulation tool. Energy Procedia, 117, 180-189.

[33] Renu Sharma, Sonali Goel. Performance analysis of a $11.2 \mathrm{kWp}$ roof top grid-connected PV system in Eastern India. Energy Report, 3, 76-84.

[34] P. Yadav, N. Kumar, S.S. Chandel. (2015) Simulation and performance analysis of a $1 \mathrm{kWp}$ photovoltaic system using Pvsyst. Proceeding of International Conference on Computation of Power, Energy, Information and Communication (ICCPEIC), Chennai, 0358-0363.

[35] W.R. Anis, M.A.S. Nour. (1995) Energy losses in photovoltaic systems. Energy Convers. Manag., 36, 11 1107-1113.

[36] I. Lillo-Bravo, P. González-Martínez, M. Larrañeta, J. Guasumba-Codena. (2018) Impact of energy losses due to failures on photovoltaic plant energy balance. Energies, 11(2), 363.

[37] Nallapaneni ManojKumar et al. (2019) Performance, energy loss, and degradation prediction of roofintegrated crystalline solar PV system installed in Northern India. Case Studies in Thermal Engineering, 13, 100409.

[38] Irfan Jamil, Jinquan Zhao, Li Zhang, Rehan Jamil, and Syed Furqan Rafique. (2017) Evaluation of Energy Production and Energy Yield Assessment Based on Feasibility, Design, and Execution of $3 \times 50 \mathrm{MW}$ GridConnected Solar PV Pilot Project in Nooriabad. International Journal of Photoenergy, 1-18.

[39] Ministry of Industry and Trade of the Socialist Republic of Vietnam. (2015) Maps of Solar Resource and Potential in Vietnam.

[40] Stefan Krauter, Ricardo Rüther. (2004) Considerations for the calculation of greenhouse gas reduction by photovoltaic solar energy. Renewable Energy, 29(3), 345-355.

[41] http://vie.jcmvietnam.vn/ 